passada debaixo dessas grossas paredes, feitas de taipas de pilāo, deste magestoso edificio, que é a tradicional Faculdade de Direito de São Paulo, o qual, se outra cousa mais proveitosa aqui nāo fez, ao menos, empregou o seu tempo, mandando corrigir os erros ortograficos e de sintaxe, colocar as estampilhas, que faltavam, repelindo, com leve admoestação, as não adequadas, e providenciando com animo e prudencia sobre assunto de somenos importancia, pelo que era tido e havido como exigente e ranzinza, mas, não obstante, se esforçou em manter a lei, a ordem e a disciplina e soube captar a simpatia dos lentes, da classe academica e dos scus auxiliares, os quais, por varias vezes, lhe deram justos motivos de jubilo e de grande apreço, amenizando-lhe assim a sua ardua tarefa.

Agora, meus eternos agradecimentos á ilustrada Congregação dos Professores, que promoveu esta homenagem, ás brilhantes e bondosas palavras, com que me saudou o joven e apreciado orador, representante do Centro Academico XI de Agosto, á classe academica a demonstração de afeto, que sempre me dispensou, e aos funcionarios, que aqui ficam, a dedicação, com que se portaram, na execução dos serviços, durante o tempo, em que dirigi a Secretaria; a todos, enfim, Professores, academicos e funcionarios. meus mais sinceros agradecimentos pela coadjunção no desempenho desse meu espinhoso cargo. De todos levo imorredouras saudades e a todos apresento as minhas despedidas.

Ao encerrar-se a sessão, o professor $\mathrm{dr}$. Reynaldo Porchal declarou inaugurada a nova sala de aulas sob o nome de "Sala Joāo Mendes Junior"

A essa expressiva homenagem á memoria do grande jurisconsulto, professor e magistrado brasileiro, estiveram presentes membros da familia do dr. João Mendes Junior, dentre os quais o seu irmão dr. Angelo Mendes de Almeida.

\title{
DR. JULIO MAIA
}

\section{ARTHUR F. DE OLIVEIRA}

Artigo publicado na "Terra Vermelha" "orgâu dos academicos de direito da colonia de Ribeirão Prelo", fasc. 5, Novembro de 1934.

Ainda sôam claramente em meus uuvidos os calorosos aplausos com que a mocidade academica da Faculdade de Direito de São 
Paulo, se despediu do dr. Julio Maia, antigo Sccretario da velha Academia. Foi em sessão solene realizada no dia 14 do corrente que ele emocionado de lá se retirou em virtude de ter sido ha pouco aposentado.

Qual o ginasiano, que ainda para terminar o seu curso de humanidades e que tendo a intenção de seguir o curso juridico, já não terá ouvido falar a respeito do dr. Julio Maia?

Em toda a parte era conhecida a sua fama padrão de honra e zelo pelos intcresses publicos.

A todos que não tiveram a oportunidade de conbece-lo de perto, á primeira vista ficou a impressão de ser um dos mais ranzinzas dos seres humanos. Mas, aqueles que o conbeceram em seu honrado cargo e que por certo tempo tiveram convivencia com ele, são unanimes em afirmar sua excelsa bondade. Era a ansia sempre dominante de cumprir o seu dever, que vinha prejudicar a sua propria bondade, mesmo parecendo a alguns que ela não existia.

Julio Maia, sózinho examinava sobre a sua mesa, um a um todos os documentos apresentados pelos candidatos a "calouros" e era ainda quem continuava a observa-los até que terminassem o curso caso lograssem aprovação nos exames vestibulares.

Todos tremiam diante deste integro cidadão, quando ele ao duvidar da veracidade de um certo documento exigia-o de novo e o candidato que se locomovesse o mais depressa possivel se quisesse sua inscrição para aquele ano. Cabendo a ele esta tarefa, tinha ocasião de vêr diante de si centenas de candidatos e nada disso o exaltava, pois que calmamente atendia a todos sempre dando tempo para tudo e atenção para todos.

Com tal escrupulo desempenhou o seu cargo de secretario, que dizem na Faculdade, que o mesmo em suas horas vagas, gastava o seu tempo examinando mais uma vez todos os documentos para vêr se estavam em perfeita ordem e se não faltavam algumas estampilhas para serem pregadas. e caso encontrasse alguns documentos desta natureza, era chamado o estudante interessado, tendo que legalizá-lo imediatamente.

Julio Maia, que durante quasi 50 anos ocupou o cargo de secretario da Faculdade de Direito de São Paulo é aquele mesmo varão ilustre que no dia 14 do corrente recebeu os mais estrondosos aplausos da classe academica. Tendo visto um exercito de bachareis desfilar diante da sua mesa de secretario; tendo assistido a tantas batalhas civicas promovidas pelos academicos do velho convento do Largo S. Francisco; estando por varias vezes ao lado dos estudantes, assistindo tambem a memoraveis campanhas civicas levadas a efeito pela palavra em comicios ruidosos quer pelas barricadas heroicas em lutas sangrentas; tendo visto vultos ilustres passarem 
sob as arcadas escalando depois o mais alto degráu da administracão politica nacional; tambem viu o seu grande zĉlo glorificado e sua grande alma, compreendida por todos, assistindo emocionado a saudação entusiastica da geração academica de 1934, que estremeceu as paredes coloniais do velho templo do Direito.

Julio Maia deixou a Faculdade de Direito de S. Paulo, causando comoçāo a todos os coraçōes que se abriram para guardit-lo cternamente.

Embora, deixando-nos, depois de acostumados a vèr aquele padrão de virtude e de bondacle, traremos sempre na memoria sua imagem querida e no coração uma gratidāo imorredoura.

Arcadas, Novembro de 1934.

\section{PROMOÇõES POR MEDIAS}

O professor dr. Waldemar Ferreira, vice-dirotor da Faculdade de Direilo de São Paulo, cm exercicio, dirigiu ao deputado á Camara Federal, professor dr. Alcantara Machado, o telegrama seguinte, que foi lido em sessão, a 21 de Novembro:

"A congregação da Faculdade de Direito de São Paulo, tendo dirigido apelo á Camara dos Deputados para rejeição do projeto de aprovação por médias, solicita eminente colega todo empenho no mesmo sentido. - Dr. Waldemar Ferreira, vice-diretor da Faculdade de Dircito de São Paulo.

Inquirido por um redator do "Diario de São Paulo" acêrca da questão, assim se exprimiu o professor dr. Waldemar Ferreira:

"Baixou tanto o nivel do ensino superior e secundario cm nosso pais, devido ás medidas de desmoralização de um c de outro, provindas das autoridades superiores, emanadas do poder legislativo, que a Segunda Constituinte Republicana tom ou sobre si a missão de impedir o desenvolviniento da avalanche.

Muito de industria, vedou $\circ$ art. 158 da Constituição de 16 de julho de 1934 "a dispensa de concurso de titulos e provas no provimento dos cargos do magisterio oficial, bem como, em qualquer curso, a de provas escolares de habilitação, determinadas em lei ou regulamento".

"Supunha-se, e agora bem se percebe que não sem certa ingenuidade, que estava liquidada, definitivamentc, a enfermidade periodica, e quasi fatal, que em todos os dezembros, se apoderava da mocidade universitaria brasileira. 